\title{
COMPARISON OF DROPERIDOL, HALOPERIDOL AND PROCHLORPERAZINE AS POSTOPERATIVE ANTI-EMETICS
}

\author{
Edward A. Loeser, George Bennett, Theodore H. Stanley, and Richard Machin
}

Prochlorperazine (Compazine) has been used for many years as a post-operative anti-emetic. Recent reports have shown that the butyrophenones, droperidol and haloperidol, also have anti-emetic properties. ${ }^{-5}$ This study was undertaken to compare the effectiveness of droperidol, haloperidol and prochlorperazine with a placebo, normal saline, as post-operative anti-emetics in patients who began to vomit in the recovery room early after operation.

\section{Methods}

This investigation was approved by the University of Utah Hospital Human Experimentation Committee. Sixly-five post-operative patients, who had previously given informed written consent for inclusion in the study and who had one or more episodes of vomiting in the recovery room, were the experimental subjects.

All patients received pentobarbitone (50$100 \mathrm{mg}$ ) or diazepam $(5-10 \mathrm{mg})$, atropine $(0.2-$ $0.5 \mathrm{mg}$ ) and meperidine (50-100 $\mathrm{mg}$ ) or morphine (5-10 mg), intramuscularly for premedication 90 minutes before arrival in the operating room. Anaesthesia was induced with sodium thiopentone $4 \mathrm{mg} \cdot \mathrm{kg}^{-1}$ intravenously and the trachea was intubated after paralysis with intravenous succinylcholine $1.5 \mathrm{mg} \cdot \mathrm{kg}^{-1}$. Anaesthesia was maintained with halothane ( $0.5-2.0$ per cent) or enflurane ( $1-3$ per cent) and nitrous oxide ( 60 per cent) in oxygen. Paralysis was maintained with increments of pancuronium $1-3 \mathrm{mg}$ intravenously for general surgical, gynaecological, or orthopedic operations. Patients included in the study were those who vomited one or more times in the recovery room. Immediately after the vomiting episode, the experimental subjects were given a two milliliter intramuscular injection of the contents of an unlabeled, numbered vial. The

Edward A. Loeser, M.D., Instuctor; George Bennett, M.D. Assistant Professor; Theodore H. Stanley, M.D., Professor; Richard Machin, D.D.S., Resident; Department of Anesthesiology,

University of Utah College of Medicine

50 North Medical Drive

Salt Lake City, Utah 84132

Canad. Anaesth. Soc. J., vol. 26, no. 2, March 1979 contents of the vial were either haloperidol $2 \mathrm{mg}$, droperidol $5 \mathrm{mg}$, prochlorperazine $10 \mathrm{mg}$ or normal saline $2 \mathrm{ml}$.

Efficacy of treatment was evaluated by one of two individuals, who were unaware of the medication administered, at the end of the following intervals: 0-30 minutes, 30 minutes-1 hour, 1-2 hours, 2-3 hours, 3-4 hours, and 4-24 hours after drug administration. Response was evaluated according to the following schema: $0=$ no nausea or vomiting (marked improvement) during the interval; $1=$ one or more episodes of nausea and up to two episodes of vomiting (mild improvement) during the interval; $3=$ nausea and more than two episodes of vomiting (no improvement) during the interval. Mean scores for each of the four groups were recorded and statistical analysis made utilizing the chi-square test.

\section{Results}

Premedication, anaesthetic technique, mean weight and age of the patients and mean duration of operation were similar in the four groups. Haloperidol, droperidol and prochlorperazine all demonstrated significant anti-emetic activity at some time during the study when compared with saline (Tables I and II). The most striking differences between the drugs were in the onset of action and duration of anti-emetic activity. Haloperidol demonstrated extremely rapid and very potent effectiveness during the first $0-30$ minutes after treatment. This activity then decayed over the following four hours. In contrast, the anti-emetic action of droperidol and prochlorperazine only became significant during the second study interval (30-60 minutes after treatment). Indeed droperidol was the slowest of the three drugs, reaching its peak effectiveness three to four hours after administration. The onset of action and duration of effectiveness of prochlorperazine appeared to be between the other two anti-emetics studied, with onset after one-half hour and duration up to four hours. Droperidol was the only drug showing evidence of prolonged anti-emetic action during the 4 to 24 hour interval after administration. 125 
TABLE I

Emesis Score Following anti-emetic administration in 65 Postoperative Patients (Mean \pm SD)

\begin{tabular}{lcccccc}
\hline \hline & $0-0.5 \mathrm{hr}$ & $0.5-1 \mathrm{hr}$ & $1-2 \mathrm{hr}$ & $2-3 \mathrm{hr}$ & $3-4 \mathrm{hr}$ & $4-24 \mathrm{hr}$ \\
\hline Droperidol & .83 & $.67^{*}$ & $.50 \ddagger$ & $.33 \ddagger$ & $.17 \ddagger$ & $.73 \ddagger$ \\
Haloperidol & \pm .22 & \pm .31 & \pm .32 & \pm .17 & \pm .08 & \pm .29 \\
& $.07 \ddagger$ & $.40 \ddagger$ & $.33 \ddagger$ & $.40 \ddagger$ & $.52 \dagger$ & 1.3 \\
Prochlorperazine & \pm .02 & \pm .09 & \pm .08 & \pm .10 & \pm .17 & \pm .41 \\
& .93 & $.20 \ddagger$ & $.20 \ddagger$ & $.47 \ddagger$ & $.40 \ddagger$ & 1.25 \\
Saline & \pm .21 & \pm .09 & \pm .08 & \pm .15 & \pm .14 & \pm .39 \\
& 1.15 & 1.25 & 1.25 & 1.05 & .80 & 1.55 \\
& \pm 1.01 & \pm 1.12 & \pm 1.12 & \pm 1.23 & \pm 1.12 & \pm 1.30 \\
\hline
\end{tabular}

$\rightarrow \mathrm{P}<0.05$

$\dagger P<0.01$.

$\ddagger P<0.005$ using Chi Square Test when compared to Saline.

TABLE II

incidence of Vomiting following Anti-emetic Administration in 65 Postoperative Patients (Per cent)

\begin{tabular}{lcccccc}
\hline \hline & $0-0.5 \mathrm{hr}$ & $0.5-1 \mathrm{hr}$ & $1-2 \mathrm{hr}$ & $2-3 \mathbf{h r}$ & $3-4 \mathrm{hr}$ & $4-24 \mathrm{hr}$ \\
\hline Droperidol & 50 & 50 & $33 \dagger$ & $33^{*}$ & $17 \dagger$ & $33 \dagger$ \\
Haloperidol & $7 \ddagger$ & $20 \ddagger$ & $13 \ddagger$ & $20 \dagger$ & 37 & 67 \\
Prochlorperazine & 47 & $7 \ddagger$ & $13 \ddagger$ & $20 \dagger$ & $13 \dagger$ & 50 \\
Saline & 70 & 70 & 70 & 55 & 50 & 64 \\
\hline
\end{tabular}

*P $<0.05$

$+\mathbf{P}<0.01$

$\ddagger P<0.005$ using Chi Square Test when compared to Saline.

\section{Discussion}

These data demonstrate that onset of the antiemetic action of haloperidol is rapid and marked (within one-half hour) but its duration is short at this dosage. Prochlorperazine is slower in onset (0.5-1 hour period), effective for four hours, and then decays. Prochlorperazine is not an effective anti-emetic for the 4-24-hour period after initial emesis. Droperidol has the slowest onset of action but has a more prolonged duration of effectiveness than any of the other drugs tested.

Vomiting is a complicated reflex mediated by the vomiting center and influenced by the chemoreceptor trigger zone, both of which are in the medulla. ${ }^{6}$ The butyrophenones (haloperidol and droperidol) are thought to exert their antiemetic actions by blocking chemoreceptor trigger zone excitation. ${ }^{7}$ Prochlorperazine (a phenothiazine) is thought to act similarly. ${ }^{8}$ Both the butyrophenones and phenothiazine may also inhibit excitation of the vomiting center directly. ${ }^{6-8}$

The mechanism(s) responsible for the different onset of action and duration of anti-emetic activity of the three compounds evaluated in this study is unknown but may be related to differences in diffusion to the chemoreceptor trigger zone or vomiting center, retention of the compounds in these areas, metabolism, or excretion. A careful comparison of the diffusability into and retention within brain tissue, metabolis $m$, and excretion of the three compounds has not been accomplished. However, there is evidence that while both haloperidol and droperidol are rapidly metabo. lized, after intravenous or intramuscular administration, the serum half-life of the former compound is significantly longer than that of the latter. ${ }^{9,10}$ Work by Soudijn, Van Wijngaarden and Allewijn with an array of radioactively tagged neuroleptic compounds of the butyrophenone type demonstrate that excretion of droperidol is greater than that of haloperidol during the first 24 hours following subcutaneous administration." The same authors have data which indicate that anti-emetic activity of the butyrophenones is due to the unaltered butyrophenone molecule (metabolites are not effective anti-emetics) ' and are primarily dependent upon blockade of dopaminergic neurones in the chemoreceptor trigger zone. All of the above suggest that while 
unaltered haloperidol probably penetrates to the chemoreceptor trigger zone in the medulla faster than droperidol, droperidol is probably retained at this site longer or is more effective as an antiemetic than haloperidol.

Complications of intravenous administration of the butyrophenones and phenothiazines are similar and consist of drowsiness, extra. pyramidal actions, hepatic dysfunction, hypersensitivity reactions and hypotension. It has been suggested that hypotension seen following administration of the butyrophenones, particularly haloperidol, is less severe and less common than that seen after comparable doses of the phenothiazines. ${ }^{8}$ This may also be true of hepatic dysfunction. These differences may be important in choosing an anti-emetic for patients with cardiovascular or hepatic disease.

Differences in the onset and duration of antiemetic activity of the three compounds studied suggest that a combination of two of them (haloperidol and droperidol) may be more effective in producing anti-emetic action of rapid onset and long duration than any one of them alone. Whether such a combination of compounds is, indeed, more effective than either of the drugs alone is unknown. Likewise, it is not known whether the side-effects of such a combination would be more detrimental than the advantages. The results of our study suggest, therefore, that additional investigations employing combinations of anti-emetics should be done.

\section{SUMMARY}

The results of this study demonstrate that prochlorperazine, haloperidol and droperidol are all effective post-operative anti-emetic compounds when compared to saline but vary in onset of activity and duration of action. Haloperidol has the shortest onset of action, being effective within 30 -minutes of intravenous administration. Prochlorperazine has an intermediate onset of action and droperidol is the siowest of the three compounds but the only one to provide significant anti-emesis 4-24 hours following administration. Our data suggest that a combination of haloperidol and droperidol may be more effective as an anti-emetic than any one of the compounds used alone.

\section{RÉSUMÉ}

Cette étude a pour objet l'évaluation compara- tive des propriétés anti-émétiques du dropéridol, de l'halopéridol, de la prochlorpérazine et du soluté physiologique administrés par la voie intramusculaire à 65 opérés ayant vomi en salle de réveil. L'évaluation a été effectuée à l'aide d'un système de points assignés sur une période déterminée. L'halopéridol s'est avéré très puissant et à début d'action très rapide, son efficacité apparaissant en deçà de trente minutes et déclinant dans les quatre heures suivantes. L'activité du dropéridol s'est manifestée beaucoup plus lentement mais son effet maximal est survenu quatre heures après l'administration. C'est le seul anti-émétique donk l'action s'est prolongée. Quant à la prochlorpérazine, son activité se situe entre l'halopéridol et le dropéridol. Ces données portent à croire que l'association halopéridol pourrait être plus efficace comme anti-émétique qu'aucun des médicaments étudiés utilisé seul.

\section{REFERENCES}

I. Shields, K.G., Ballinger, C.M., \& HathawAY, B.N. Antiemetic effectiveness of haloperidol in human volunteers challenged with apomorphine. Anesth. and Analg. 50 : 1010 (1971).

2. TORNETTA, F.J. Double-blind evaluation of haloperidol for antiemetic activity. Anesth. and Analg. 51: 964 (1972).

3. Barton, M.D., Libonati, M., Cohen, C.J. The use of haloperidol for treatment of postoperative nausea and vomiting - a double-blind placebocontrolled trial. Anesthesiology 42: 508 (1975).

4. PATron, JR., C.M., Moon, M.R., DANnemil. LER, F.J. Prophylactic antimetic effect of droperidol. Anesth. and Analg. 53 : 361 (1974)

5. Winning, T.J., Brock-UTNe, J.G., \& Downing J. W. Nausea and vomiting after anesthesia and minor surgery. Anesth. and Analg. 56: 674 (1977).

6. Borison, H.L. \& WANG, S.C. Physiology and pharmacology of vomiting. Pharmacol. rev, $5: 193$ (1953).

7. SOUdIJN, W., VAN WuingaARden, I., \& JANSSEN, P.A.J. Biotransformation of neuroleptanalgesics. Int. Anesth. Clin. 12:145 (1974).

8. GoOdMan \& Gllman. The pharmalogical basis of therapeutics, fifth editon, New York, MacMillan Publishing Company, p. 166 (1975).

9. Cressman, W.A., Plotnicks, J., Johnson, P.C. Absorption, metabolism and excretion of droperidol by human subjects following intramuscular and intravenous administration. Anesthe siology $38: 363$ (1973).

10. Forsman, A. \& Ohman, R. Phamacokinetic studies on haloperidol in man. Curr. Therap. Res. 20: 319 (1976).

11. SoudiJn, W.. Van WiJingaARden, I., \& ALLEWIJN, F. Distribution, excretion, and metab. olism of neuroleptics of the butyrophenone type. Eur. J. Pharmacol. I: 47 (1967). 